\title{
The Chemical Compounds of Flacourtia rukam Leaves and Their Inhibition of Anggiotensin- converting Enzyme (ACE) Activity
}

\author{
Muharni Muharni ${ }^{*}$, Heni Yohandini ${ }^{1}$, Elfita Elfita ${ }^{1}$, Fitrya Fitrya ${ }^{2}$, Ani Sarah ${ }^{1}$, Rifdah Nabila ${ }^{2}$ \\ 'Department of Chemistry, Faculty of Mathematics and Natural Sciences, University of Sriwijaya, Jl. Raya \\ Palembang-Prabumulih Km 32, Indralaya, Ogan Ilir, South Sumatra, Indonesia. \\ ${ }^{2}$ Department of Pharmacy, Faculty of Mathematics and Natural Sciences, University of Sriwijaya, Jl. Raya \\ Palembang-Prabumulih Km 32, Indralaya, Ogan Ilir, South Sumatra, Indonesia. \\ *Corresponding authot email: muharnimyd@yahoo.co.id
}

Received July 05, 2021 ; Acepted September 10, 2021 ; Available online November 15,2021

\begin{abstract}
Flacourtia rukam is a popular plant to treat hypertension, especially the Musi Banyuasin of South Sumatera, Indonesia. Isolation and identification of chemical compounds from F. rukam leaves and evaluation of their effects on antihypertensive activity have been conducted. Isolation of chemical compounds using chromatographic methods and identification using spectroscopic methods were compared with the reported data. The drug's effects on antihypertension were determined using the angiotensin-converting enzyme (ACE) inhibitory method. Two compounds have been isolated from the leaves of $F$. rukam and identified as apigenin $(1,20 \mathrm{mg})$ and lupeol $(2,17 \mathrm{mg})$. Lupeol (2) was first reported and isolated from the leaves of $F$. rukam. These compounds were demonstrated to be effective in treating antihypertension with $15.12 \pm 0.72 \mu \mathrm{g} / \mathrm{mL}$ for apigenin and $\mathrm{IC}_{50} 656.51 \pm 1.55 \mu \mathrm{g} / \mathrm{mL}$ for lupeol. It can be concluded that $F$. rukam leaves are a potential ACE inhibitor that can be explored further as an effective antihypertensive agent.
\end{abstract}

Keywords: Antihypertension activity, apigenin, Flacourtia rukam, lupeol, ACE

\section{INTRODUCTION}

The research on bioactive compounds in traditional medicine is moving forward. An ethnobotany survey of traditional drugs in Indonesia identified many medicinal plants traditionally used but not supported by scientific data. One common disease in the community is hypertension, a clinical syndrome defined as systolic blood pressure $\geq 140 \mathrm{mmHg}$ and diastolic blood pressure $\geq 90 \mathrm{mmHg}$ (Oparil et al., 2019). Hypertension can trigger various diseases such as coronary heart disease, stroke, and heart failure. These complications can increase mortality (Fuchs \& Whelton, 2020).

One traditional medicine used to treat hypertension is $F$. Rukam, a plant belonging to the family Flacourtiaceae and in Indonesia is known as rukem (Heyne, 1987). This plant is widely used in South Sumatra to treat hypertension (Yustian, Muharni, Sukarmi, Arbi, \& Zulaika, 2012). F. rukam is a shrub 5-15 m high, with a leaf diameter of about 6 $\mathrm{cm}$, thorny stems up to $10 \mathrm{~cm}$, young leaves measuring 4-8 mm, mature leaves 6-16 $\times 4-7 \mathrm{~cm}$, yellowish-green flowers, and young green to mature red fruit with a diameter of 2-2.5 cm (Heyne, 1987). Based on previous studies, the leaves of $F$. Rukam are also used to treat eyelid inflammation. Postpartum women use the roots as an antiseptic, and the young leaves can be eaten directly (Ragasa et al., 2016).

In Thailand, the F. Rukam wood is used to treat skin infections (Chusri, Chaicoch, Thongza-ard, Limsuwan, \& Voravuthikunchai, 2012). Ragasa et al. (2016) reported that the chemical content steroid compounds, chlorophyll and glycerol derivatives of the F. rukam fruit. Glycerol derivates are active as anti-inflammatory agents. (Imbs, Ermakova, Fedoreyev, Anastyuk, \& Zvyagintseva, 2013) and cytotoxic (Nguyen et al., 2004; Tsai, de Castro-Cruz, Shen, \& Ragasa, 2012). Thai et al. (2020) have reported four compounds from F. rukam stems led, while three compounds others have reported by Muharni Elfita, Heni, Yasrina, \& Miranti (2019) from the stem bark. The similar compound (fliedelin) from the F. rukam stem bark also to reported from the root (Muharni et al., 2019). Seventeen phenolic compounds of $F$. rukam leaves and bark led also have been reported and one amoung the compound is apigenin (Afifi et al., 2021). Phytochemical assay of ethanol extracted from the F. rukam leaves indicated terpenoid, steroid, flavonoid, and phenol compounds (Muharni, Fitrya, \& Nurmaliana, 2016). Two compounds, apigenin (1) and lupeol (2) were isolated from the leaf extract. 
This study evaluated the isolation, structure elucidation, and antihypertensive activity assay of these compounds. The antihypertensive activity of these compounds was determined using the angiotensin converting enzyme (ACE) inhibitory method (Arihara, Nakashima, Mukai, Ishikawa, \& Itoh, 2001).

\section{EXPERIMENTAL SECTIONS}

\section{General Experiment Procedure}

The UV spectrum was recorded on single-beam Shimadzu-UVmini-1240. The IR spectrum in $\mathrm{KBr}$ was recorded on a Perkin Elmer-FTIR spectrometer. The NMR spectra were recorded on an Agilent DD2 (500 $\mathrm{MHz}$ for $1 \mathrm{H}-\mathrm{NMR}$ and $125 \mathrm{MHz}$ for 13C-NMR). Ultraviolet lamps were the CAMAG UV lamp dual wavelength $(\lambda=254$ and $365 \mathrm{~nm})$. Chemicals and reagents used in this study were purchased from Sigma-Aldrich and Merck.

\section{Plant Materials}

Fresh leaves from the F. rukam were collected in January 2019 from the Regency of Musi Banyuasin, South Sumatera, Indonesia, and identified by Dr Laila Hanum, Head of the Botany Laboratory, University of Sriwijaya. The voucher specimen was deposited in the laboratory (specimen number VIC 2702).

\section{Preparation of Extracts}

Fresh leaves from $F$. rukam were cut into small pieces $(600 \mathrm{~g})$ and extracted using $n$-hexane $(2.5 \mathrm{~L})$ solvent by the maceration method for 24 hours. The extraction process was repeated three times using a rotary evaporator at about $50^{\circ} \mathrm{C}$ to dryness to obtain a crude $n$-hexane extract The residue was then reextracted successively with ethyl acetate and methanol. Each extract was concentrated to yield a crude ethyl acetate and methanol extract (Metasari, Elfita, Muharni, Yohandini, 2020).

\section{Fractionations and Purification}

The ethyl acetate extract $(15 \mathrm{~g})$ was separated using vacuum column chromatography with silica gel G $60(120 \mathrm{~g})$ as a stationary phase. The sample was prepared using pre-adsorption with a silica gel 70 230 mesh at a ratio of $1: 1$. Furthermore, elution was conducted with $n$-hexane and then with a solvent $n$ hexane : ethyl acetate (9:1-5:5). The elvent was collected in $500 \mathrm{~mL}$ bottles and evaporated. TLC analysis identified the component UV light and cerium sulfate to the component viewer. The eluent showed the same TLC patterns combined into one fraction, then concentrated to obtain five fractions: F1 (3.202 g), F2 (1.224 g), F3 (2.520 g), F4 (0.742 g), and F5 $(5.421 \mathrm{~g})$. Fraction F5 $(5 \mathrm{~g})$ was fractionated using gravity column chromatography with silica gel 70-230 mesh $(60 \mathrm{~g})$ as a stationary phase and a solvent by gradually increasing the polarity with ethyl acetate in $n$-hexane for elution (9:1-5:5). The eluent showed the same TLC patterns combined into one fraction and then concentrated to obtain five fractions: F5.1 (1.152 g), F5.2 (0.675 g), F5.3 (1.554 g), F5.4 (0.543 g), and F5.5 $(0.422 \mathrm{~g})$. The F5.5 $(0.422)$ fraction was purified again using gravity column chromatography. The elvent showed the same TLC patterns combined into one fraction, then concentrated to obtain five fractions: F5.5.1 (102 mg), F5.5.2 (51 mg), F5.5.3 (71 mg), F5.5.4 (103 mg), and F5.5.5 (62 mg). In F5.5.1, the fraction was obtained from white crystalline needles $(1,20 \mathrm{mg})$.

The methanol extract (10 g) was separated using vacuum column chromatography. The sample was prepared by pre-adsorption using silica gel 70-230 mesh, and elution was carried out in the mobile phase using a solvent with a mixture of $n$-hexane: ethyl acetate $(5: 5,4: 6,3: 7,2: 8$, and $1: 9)$ and ethyl acetate: methanol (9:1). The filtrate was concentrated and analyzed using TLC. Samples showing the same stain pattern were combined into one fraction (F1-F4). The fraction (F3) was then separated using gravity column chromatography with a diameter of $2 \mathrm{~cm}$ (Roge et al., 2011). Pre-adsorption was conducted on the selected fraction (F3) using a solvent similar to the fraction. Samples were eluted using a mixture of $n$-hexane: ethyl acetate $(5: 5,4: 6 ; 3: 7,2: 8$, and $1: 9)$ and ethyl acetate $100 \%$, each $200 \mathrm{~mL}$. The resulting eluate was collected in vials $( \pm 10 \mathrm{~mL})$ and identified using TLC. Vials with the same stain were combined into one fraction (F3.1-F3.6). The subfraction F3.4 showed greenish-white crystals, and after purification with $n$ hexane, white crystals $(2,17 \mathrm{mg})$ were well soluble in chloroform.

\section{Antihypertensive Activity by Angiotensin Converting Enzyme (ACE) Inhibition.}

Invitro antihypertensive activity was determined based on ACE inhibitor activity according to the method described by Arihara et al. (2011). Eighty (80) $\mu \mathrm{L}$ of the sample (series concentrations 100, 200, 300,400 , and $500 \mu \mathrm{g} / \mathrm{mL}$ for sample, and 10, 20, 30,40 , and 50 for standard captopril $\mu \mathrm{g} / \mathrm{mL}$ ) was mixed with $50 \mu \mathrm{L}$ of hippuryl-L-histidyl-L-leucine $(\mathrm{HHL})$ buffer $(2.5 \mathrm{mM} \mathrm{HHL}$ in $0.05 \mathrm{M}$ of sodium borate buffer $\mathrm{pH}$ 8.3), then $15 \mu \mathrm{L}$ bovine serum albumin (BSA); the mixture was allowed to stand for five min at $37^{\circ} \mathrm{C}$ and then added $50 \mu \mathrm{L}$ ACE (0.05 units $/ \mathrm{mL})$. The mixture was allowed to stand for $60 \mathrm{~min}$ at $37^{\circ} \mathrm{C}$. The reaction was stopped by adding $250 \mu \mathrm{L}$ of $0.5 \mathrm{M} \mathrm{HCl}$ and 1.7 $\mathrm{mL}$ of ethyl acetate, forming hippuric acid. The mixture was then centrifuged at a speed of $10,000 \mathrm{rpm}$ for 10 min. An $800 \mu \mathrm{L}$ supernatant was oven-dried at $95^{\circ} \mathrm{C}$ for $75 \mathrm{~min}$. The resulting hippuric acid was dissolved into $1,000 \mu \mathrm{L}$ of aqua dest. Absorbance was measured at a wavelength of $228 \mathrm{~nm}$ using a UV-Vis spectrophotometer. As a control positive ACE inhibitor using captopril. The activity of the ACE inhibitors was calculated using the formula:

(\%) inhibitor activity $A C E=(A-B)-(C-D) /(A-B) \times 100 \%$ 
$A=$ Absorbance control (substrate $\mathrm{HHL}+$ enzyme ACE)

$B=$ Absorbance blank control (substrate $\mathrm{HHL}+$ aquades)

$\mathrm{C}=$ Absorbance sample (substrate $\mathrm{HHL}+$ enzyme $\mathrm{ACE}+$ sample)

$\mathrm{D}=$ Absorbance blank sample (substrate $\mathrm{HHL}+$ sample)

\section{Data Analysis}

The ACE inhibition activity experiment was carried out in triplicate. Data were expressed as mean \pm SD. The percent inhibition and $I C_{50}$ were determined using analysis of variance (ANOVA) alfa 0.05 , followed by a Duncan new multiple range test (DNMRT) at alfa 0.05 using the Statistical Package for the Social Science (SPSS 14) software.

\section{RESULTS AND DISCUSSION}

The extraction $(600 \mathrm{~g})$ of fresh F. rukam leaves was accomplished using the maceration method with a step gradient polarity solvent ( $n$-hexane, ethyl acetate, and methanol) and after evaporation to generate the crude $n$-hexane extract $(28.97 \mathrm{~g})$, ethyl acetate extract $(16.49 \mathrm{~g})$, and methanol $(28.98 \mathrm{~g})$. We successfully isolated pure compounds in the form of yellow crystalline $(20 \mathrm{mg} \mathrm{1})$ from ethyl acetate extract with a melting point of $340-343^{\circ} \mathrm{C}$ and a pure compound of white crystalline needles $(17 \mathrm{mg} \mathrm{2})$ from the methanol extract with a melting point of $214-216^{\circ} \mathrm{C}$.

The UV spectrum compound 1 showed patterns at $268 \mathrm{~nm}$ and $336 \mathrm{~nm}$, indicating $\mathrm{C}=\mathrm{C}$ conjugated to the aromatic ring. IR spectrum showed the absorption at 1610, 1555 and $1496 \mathrm{~cm}^{-1}$. These were characteristic $\mathrm{C}=\mathrm{C}$ aromatic, and $3093 \mathrm{~cm}^{-1}$ was characteristic of the stretching $\mathrm{C}-\mathrm{H}$ aromatic. Other absorption peaks included $3327 \mathrm{~cm}^{-1}$ for bending $\mathrm{O}$ $\mathrm{H}, 1180 \mathrm{~cm}^{-1}$ for $\mathrm{C}-\mathrm{O}$ phenol, and $1654 \mathrm{~cm}^{-1}$ for peak ketone carbonyl. The IR spectra data accordance to the IR data of apigenin available in the literature (Nayaka, Londonkar, Umesh, \& Tukappa, 2014). The ${ }^{1} \mathrm{H}$-NMR spectrum showed the chemical shifts at $\delta$ $7.91(2 \mathrm{H}, d, J=8.5)$ and $6.93(2 \mathrm{H}, d, J=8.5)$. These were characteristic of the four aromatic protons; ortho a coupled from the aromatic di substitutions. Two other aromatics proton at $6.19(1 \mathrm{H}, d, J=2)$ and 8.64 $(1 \mathrm{H}, \mathrm{d}, J=2)$ with meta coupled. The proton NMR spectrum also showed a region of chemical signal at $12.96(1 \mathrm{H}, \mathrm{brs})$ was chelated hydroxyl. The signal at $\delta_{H} 6.78(1 \mathrm{H}, s)$ showed the presence of proton of aromatic not coupled.

The ${ }^{13} \mathrm{C}$-NMR spectrum (in $\mathrm{CD}_{3} \mathrm{OD}$ ) showed 13 carbon signals, all for carbon $\mathrm{C} \mathrm{sp}{ }^{2}$. The signal at $\delta \mathrm{c}$ 181.7 was characteristic for $C$ carbonyl ketones, which supported the absorption for a peak of a carbonyl group in the IR spectrum at $1654 \mathrm{~cm}^{-1}$. Fourteen other signals carbon signals for aromatic carbon. The HSQC spectra correlation $\delta \mathrm{H} 7.91$ to carbon at 128.5 and 6.93 to carbon at 115.9 demonstrated that each represented two carbon signals. Other signals at the HSQC spectra showed 6.78 to 102.6 carbon, 6.48 to 98.8 carbon, and 6.19 to 93.9 carbon. Based on the HSQC spectra, there were 15 carbon signals attributed to seven methine and eight quaternary carbons. The $\mathrm{HMBC}$ spectra showed a correlation proton of $\delta_{\mathrm{H}} 6.78(1 \mathrm{H}, \mathrm{s})$ to carbon at $\delta \mathrm{c} 163.7, \delta \mathrm{c}$ $181.7, \delta c 103.6$, and $\delta c 121.1$. Proton at $\delta_{H} 6.48$ to carbon at $\delta c 164.1, \delta c 157.3$, and $\delta c 103.8$. Others correlations at the $\mathrm{HMBC}$ spectra proton included $\delta_{\mathrm{H}}$ 6.19 to carbon at $\delta c 102.6$, $\delta c 161.4$, and $\delta c$ 93.9. Proton at $\delta_{H} 7.91$ to carbon $\delta c 161.1$ and $\delta c 181.7$ and proton $\delta_{H} 6.93$ to carbon $\delta c 121.1$ and $\delta c 161.1$ NMR data of ${ }^{1} \mathrm{H},{ }^{13} \mathrm{C}$, and $\mathrm{HMBC}$ NMR for compounds 1 are shown in Table 1. The correlations at HMBC and HSQC for the structure of compounds 1 are shown in Figure 2. Based on these data, compound 1 was determined to be apigenin (Figure 1).

The IR spectrum compound $\mathbf{2}$ showed an absorption peak of $3377 \mathrm{~cm}^{-1}$ were characteristic of the hydroxyl group $(-\mathrm{OH})$. The hydroxyl group $(-\mathrm{OH})$ was supported by the absorption peak of $1020 \mathrm{~cm}^{-1}$ for stretching of the $\mathrm{C}-\mathrm{O}$. In addition, the absorption bands of $2959 \mathrm{~cm}^{-1}$ and $2868 \mathrm{~cm}^{-1}(\mathrm{CH}$ aliphatic asymmetric and symmetric). An additional two peaks at $1481 \mathrm{~cm}^{-1}$ and $1366 \mathrm{~cm}^{-1}$ represented bending frequencies for the $\mathrm{CH}_{2}$ and $\mathrm{CH}_{3}$ cycloaliphatic. The ${ }^{1} \mathrm{H}$ NMR spectrum $\left(500 \mathrm{MHz}, \mathrm{CDCl}_{3}\right.$ ) compound 2 (Table 2) showed a signal at $3.20 \mathrm{ppm}(1 \mathrm{H}, \mathrm{m})$, typical for $\mathrm{H}$ 3 of a triterpene type carbon skeleton. Signals at 4.56 and $4.68(1 \mathrm{H}$, each) indicated a vinylic proton at C29. Besides these, the spectrum displayed a signal multiplet of one proton at $2.36 \mathrm{ppm}$ assigned to $\mathrm{H}-19$. The spectrum also showed 2.00 and 1.98 masing $(2 \mathrm{H}$, $\mathrm{m})$ as signals for two methylene groups in the cycloaliphatic form and seven signal singlets of methyl groups at $0.75(3 \mathrm{H}, s), 0.78(3 \mathrm{H}, s), 0.82(3 \mathrm{H}, s), 0.94$ $(3 \mathrm{H}, \mathrm{s}), 0.96(3 \mathrm{H}, \mathrm{s}), 1.02(3 \mathrm{H}, \mathrm{s})$, and $1.24 \mathrm{ppm}(3 \mathrm{H}$, s). The ${ }^{13} \mathrm{C}-\mathrm{NMR}$ spectrum showed 30 carbon signals. Signals at 151.1 and 109.5 were assigned to the olefinic carbon and signal at $\delta_{c} 79.2 \mathrm{ppm}$; these are characteristic of the C-3 in triterpenoid that binds the $\mathrm{OH}$ groups. Other signals that accumulate in areas below $\delta c 60 \mathrm{ppm}$ are signals for $\mathrm{sp}^{3}$ carbon in a cycloaliphatic form for terpenoid compounds. The $1 \mathrm{H}$ and ${ }^{13} \mathrm{C}$ NMR values for all the protons and carbons (Table 2) were compared with previous values (Shwe, Win, Moe, Myint \& Win, 2019). These data confirmed that compound $\mathbf{2}$ is lupeol (Figure $\mathbf{1}$ ).

Apigenin (1) compound based on the literature study have been reported from F. rukam (Afifi et al., 2021), but there are no studies on the presence of compounds 2. This study is the first on the isolation of compounds 2 from F. rukam. The apigenin compound have been reported of $F$. rukam leaves and bark led (Afifi et al., 2021). The flavonoid compounds have been reported in other species in the genus Flacourtia. 
Table 1. ' H-NMR (500 MHz), ${ }^{13} \mathrm{C}-\mathrm{NMR}(125 \mathrm{MHz})$ data compound 1 (CD $\left.{ }_{3} \mathrm{OD}\right)$

\begin{tabular}{llll}
\hline $\begin{array}{l}\text { Carbon } \\
\text { Position }\end{array}$ & $\delta_{\mathrm{C}}$ & $\delta_{\mathrm{H}}[\Sigma \mathrm{H}$, mult., $J(\mathrm{~Hz})]$ & $\mathrm{HMBCH} \rightarrow \mathrm{C}$ \\
\hline 1 & - & - & - \\
2 & 163.7 & - & - \\
3 & 102.6 & $6.78(1 \mathrm{H}, \mathrm{s})$ & - \\
4 & 181.7 & - & - \\
5 & 161.4 & - & $163.7 ; 181.7 ; 103.8 ; 121.1$ \\
6 & 98.8 & $6.19(1 \mathrm{H}, \mathrm{d}, J=2 \mathrm{~Hz})$ & - \\
7 & 164.1 & - & $161.4 ; 157.3 ; 103.8$ \\
8 & 93.9 & $6.48(1 \mathrm{H}, \mathrm{d}, J=2 \mathrm{~Hz})$ & - \\
9 & 157.3 & - & - \\
10 & 103.8 & - & - \\
$1^{\prime}$ & 121.1 & - & $128.4 ; 161.1$ \\
$2^{\prime} / 6^{\prime}$ & 128.4 & $7.91(2 \mathrm{H}, \mathrm{d}, J=8.5 \mathrm{~Hz})$ & 121.1 \\
$3^{\prime} / 5^{\prime}$ & 115.9 & $6.93(2 \mathrm{H}, \mathrm{d}, J=8.5 \mathrm{~Hz})$ & - \\
$4^{\prime}$ & 161.1 & - & \\
\hline
\end{tabular}

Table 2. ${ }^{1} \mathrm{H}-\mathrm{NMR}(500 \mathrm{MHz}),{ }^{13} \mathrm{C}-\mathrm{NMR}(125 \mathrm{MHz})$, and DEPT data compound $2^{\mathrm{b}}\left(\mathrm{CDCl}_{3}\right)$, lupeola $\left(\mathrm{CDCl}_{3}\right)$, (Shwe et al., 2019)

\begin{tabular}{|c|c|c|c|c|}
\hline $\begin{array}{l}\text { Carbon } \\
\text { No }\end{array}$ & ${ }^{13} \mathrm{C} N \mathrm{NMR}^{a}$ & ${ }^{13} \mathrm{C} N M R^{b}$ & $\begin{array}{l}{ }^{1} \mathrm{H} \text { NMR }\left[\delta_{\mathrm{H}} \text {, mult., }\right. \\
J(\mathrm{~Hz})]\end{array}$ & ${ }^{1} \mathrm{H} N M R^{b}$ \\
\hline 1 & 38.85 & 38.22 & $0.90 ; 1.65$ & 0.99 \\
\hline 2 & 27.44 & 27.60 & $1.52 ; 1.67$ & $1.98(\mathrm{~m})$ \\
\hline 3 & 78.99 & 79.19 & $3.20(d d)$ & $3.19(\mathrm{~m})$ \\
\hline 4 & 38.70 & 38.88 & & \\
\hline 5 & 55.29 & 55.46 & 0.67 & 0.68 \\
\hline 6 & 18.31 & 18.50 & $1.37 ; 1.52$ & $1.40(\mathrm{~m})$ \\
\hline 7 & 34.27 & 34.44 & 1.39 & $1.38 ;(m)$ \\
\hline 8 & 40.82 & 40.18 & & \\
\hline 9 & 50.43 & 50.61 & 1.25 & \\
\hline 10 & 37.16 & 37.34 & & \\
\hline 11 & 20.92 & 21.10 & $1.20 ; 1.40$ & $1.15(\mathrm{~m})$ \\
\hline 12 & 25,13 & 25.30 & $1.06 ; 1.62$ & $2.00(\mathrm{~m})$ \\
\hline 13 & 38.04 & 38.88 & 1,66 & \\
\hline 14 & 42.82 & 43.00 & & \\
\hline 15 & 27.41 & 27.46 & 1,$05 ; 1,60$ & \\
\hline 16 & 35.57 & 35.76 & $1.35 ; 1.45$ & $1.40(\mathrm{~m})$ \\
\hline 17 & 42.99 & 43,00 & & \\
\hline 18 & 48.29 & 48.47 & $1.36 ; 1.37$ & \\
\hline 19 & 47.97 & 48.17 & $2.40(\mathrm{~m}): 1.45$ & $2.36(\mathrm{~m})$ \\
\hline 20 & 150.96 & 151.19 & & \\
\hline 21 & 29.84 & 29.88 & $1.3 ; 1.91(\mathrm{~m})$ & 1.25 \\
\hline 22 & 40.00 & 39.84 & $1.18 ; 1.37$ & \\
\hline 23 & 27.98 & 28.17 & $0.90(s)$ & $0.96(s)$ \\
\hline 24 & 15.36 & 15.57 & $0.76(s)$ & $0.75(s)$ \\
\hline 25 & 16.11 & 16.30 & $0.83(s)$ & $0.82(s)$ \\
\hline 26 & 15.96 & 16.15 & $1.03(s)$ & $1.02(s)$ \\
\hline 27 & 14.60 & 14.73 & $0.94(s)$ & $0.94(s)$ \\
\hline 28 & 17.99 & 18.18 & $0.79(s)$ & $0.78(s)$ \\
\hline 29 & 109.31 & 109.50 & $4.57(s) ; 4.69(s)$ & $4.56(s): 4.68$ \\
\hline 30 & 19.29 & 19.48 & $1.67(s)$ & $1.67(s)$ \\
\hline
\end{tabular}



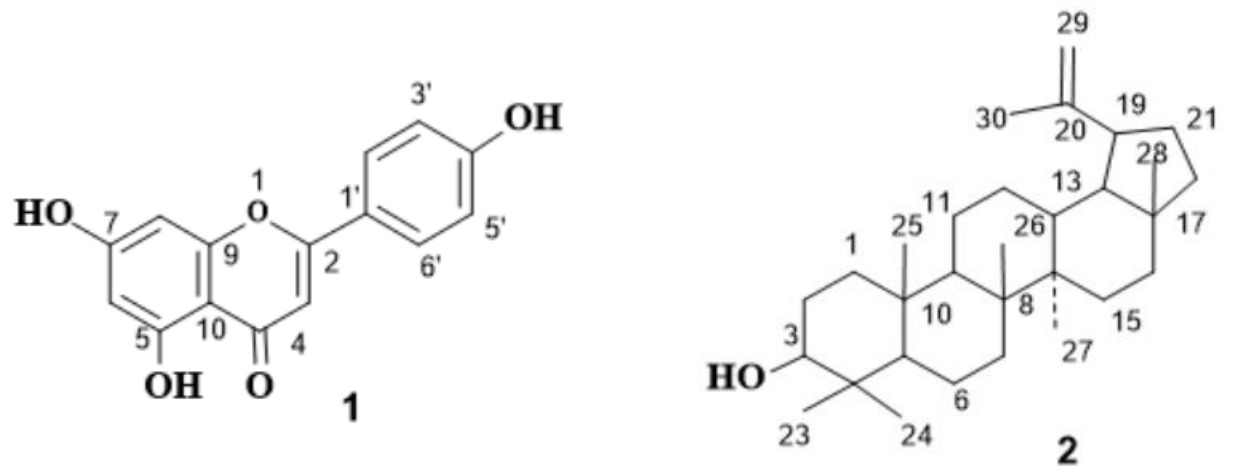

Figure 1. Chemical structures of compounds 1 and 2

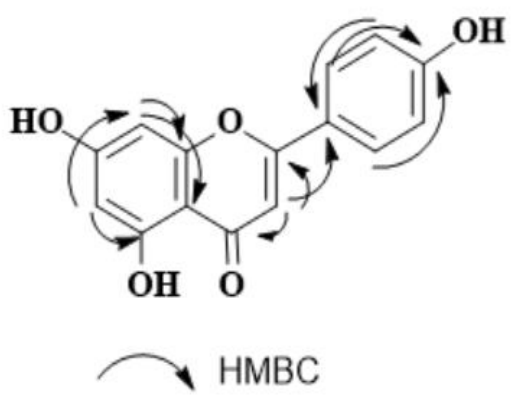

Figure 2. HMBC correlations compound 1

They include krisoeriol-7-O- $\beta$-D-glucopyranoside, catechin-[5,6-e]-4b-(3,4-dihydroxy phenyl), dihydro2(3H)-pyranone, mururin A (Sashidhara et al., 2013),

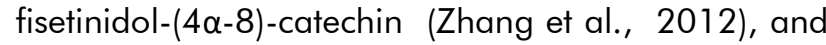
$(+)$-catechin, quercetin, luteolin, and rutin (Talukder et al., 2012). Triterpenoid has been reported from $F$. rukam, i.e., friedelin (Muharni et al., 2019).

The antihypertension activity associated with apigenin (1) and lupeol (2) were determined based on ACE (Arihara et al., 2001). The high inhibitory activity of ACE corresponds to the low concentration of hippuric acid formation (Ahmad, Yanuar, Mulia, \& Mun'im, 2017; Ozarowski et al., 2019). The activity expressed as a percentage of inhibition ACE (\% I). As standard using captopril. The higher concentration of the sample, the percentage of ACE inhibition also increases (Table 3 and 4). The statistical analysis showed the percentage of ACE inhibition was significantly different for each concentration $(P<0.05)$ of apigenin (1). For standard captopril at concentrations of 30 and $40 \mu \mathrm{g} / \mathrm{mL}$, the statistical analysis showed no significant difference $(p>0.05)$ in the level of inhibition. For concentration 40 and 50 $\mu \mathrm{g} / \mathrm{mL}$ also no significant difference ( $>0.05)$. However, there was a significant difference $(P<0.05)$ for concentrations 10 and $20 \mu \mathrm{g} / \mathrm{mL}$. For lupeol (2) at concentrations 100 and $200 \mu \mathrm{g} / \mathrm{mL}$, the statistical analysis showed no significant differences.

Table 3. ACE inhibitory activity of apigenin (1) and captopril.

\begin{tabular}{ccc}
\hline Concentration $(\mu \mathrm{g} / \mathrm{mL})$ & \multicolumn{2}{c}{$\%$ Inhibition of ACE activity \pm SD } \\
\cline { 2 - 3 } & Apigenin (1) & Captopril \\
\hline 10 & $41.38 \pm 0.48^{\mathrm{e}}$ & $45.67 \pm 2.80^{\mathrm{e}}$ \\
20 & $52.49 \pm 1.22^{\mathrm{d}}$ & $63.24 \pm 0.65^{\mathrm{c}}$ \\
30 & $63.52 \pm 0.56^{\mathrm{c}}$ & $85.54 \pm 0.57^{\mathrm{a}}$ \\
40 & $71.00 \pm 0.42^{\mathrm{b}}$ & $88.07 \pm 0.77^{\text {af }}$ \\
50 & $88.16 \pm 1.72^{\mathrm{a}}$ & $90.33 \pm 0.75^{\mathrm{f}}$
\end{tabular}

Note: Values are presented as means $\pm S D, n=3$. According to Duncan New Multiple Range Test (DNMRT), 5\%. Numbers followed by the same subscript indicate no significant difference. 
Table 4. ACE inhibitory activity of lupeol (2).

\begin{tabular}{cl}
\hline Concentration $(\mu \mathrm{g} / \mathrm{mL})$ & $\%$ Inhibition $\pm S D$ \\
\hline 100 & $6.45 \pm 1.15^{\mathrm{a}}$ \\
200 & $8.31 \pm 0.55^{\mathrm{a}}$ \\
300 & $13.39 \pm 0.72^{\mathrm{b}}$ \\
400 & $26.08 \pm 2.24^{\mathrm{c}}$ \\
500 & $41.34 \pm 2.51^{\mathrm{d}}$ \\
\hline
\end{tabular}

Note: Values are presented as means \pm SD, $n=3$, Numbers follow by the same subscript indicate no significant difference according to Duncan New Multiple Range Test (DNMRT) 5\%.

Table 5. The $\mathrm{IC}_{50}$ value of $\mathrm{ACE}$ inhibition

\begin{tabular}{ll}
\hline Sample & $\mathrm{IC}_{50}(\mathrm{mg} / \mathrm{L})$ \\
\hline Apigenin (1) & $15.12 \pm 0.72^{\mathrm{a}}$ \\
Lupeol (2) & $656.51 \pm 1.55^{\mathrm{b}}$ \\
Captopril & $12.55 \pm 0.42^{\mathrm{a}}$ \\
\hline
\end{tabular}

Note: Values are presented as mean $\pm S D, n=3$; Numbers follow by the same subscript indicate no significant difference.

$I C_{50}$ values for apigenin (1) and lupeol (2) were determined using linear regression for curve percentage inhibition versus the concentrations (Table 5). The results showed that apigenin (1) and lupeol (2) yielded IC 50 values $15.12 \pm 0.72 \mu \mathrm{g} / \mathrm{mL}$ and 656.51 $\pm 1.55 \mu \mathrm{g} / \mathrm{mL}$, while captopril had an antihypertensive standard $I C_{50}$ value of $12.55 \pm 0.42$ $\mathrm{mg} / \mathrm{L}$. The statistical analysis showed that apigenin (1) had no significant $I C_{50}$ value for ACE inhibition compared to standard captopril $(p>0.05)$. This study identified antihypertensive compounds from the leaf extract of $F$. Rukam and the potential to develop natural antihypertensive drugs. The ACE inhibitory activity of apigenin from Adinandra nitida leaves at $500 \mu \mathrm{g} / \mathrm{mL}$ is $30.27 \%$ (Liu, Yang, Ma, Yuan \& Chen, 2010). In comparison, in this study, we obtained inhibition more highest $(41.38 \%)$ and even at lower test concentrations $(10 \mu \mathrm{g} / \mathrm{mL})$. The difference in the ACE inhibitory activity of apigenin with that reported in the literature because of the difference in the methods was used. Liv et al. (2010) using colourimetry method, and measurement at a wavelength of $420 \mathrm{~nm}$ and using kit test and human serum as blanko, while in this research, absorbance was measured at a wavelength of $228 \mathrm{~nm}$.

\section{CONCLUSIONS}

Two compounds were isolated from the extract of F. rukam leaves, identified as apigenin (1) and lupeol (2). Compound 2 were the first reported from F. rukam. Invitro tests of apigenin (1) compound showed antihypertensive activity with an $I C_{50}$ value of $15.12 \pm$ $0.72 \mu \mathrm{g} / \mathrm{mL}$. It can be concluded that $F$. rukam leaves are a potential ACE inhibitor that can be explored further as an effective antihypertensive agent.

\section{ACKNOWLEDGMENTS}

The authors are thankful to the Department of Chemistry, University of Sriwijaya, for the facility for this research work. The author also thanks the research centre of chemistry, the Indonesian Institute of Sciences, Serpong, for their assistance on the NMR measurement spectrum.

\section{REFERENCES}

Afifi, N. I, Moawad, A. S., Zaki, M. A., Rateb, M. E., Rashed, M. H., Saleh, I. G., Hetta, M. H., \& Mohammed, R. B. (2021) Four new phenolics and antiparasitic secondary metabolites from Flacourtia rukam Zoll. \& Mortizi. Natural Product Research. 2021, 1-12.

Ahmad, I., Yanuar, A., Mulia, K., \& Mun'im, A. (2017). Review of angiotensin converting enzyme inhibitory assay: Rapid method in drug discovery herbal plants. Pharmacognosy Reviews, $11(21), 1-7$.

Arihara, K., Nakashima, Y., Mukai, T., Ishikawa, S., \& Itoh, M. (2001). Peptide inhibitor for angiotensin converting enzyme from enzymatic hydrolysates of porcine skeletal muscle proteins. Meat Science, 57, 319-324.

Chusri, S., Chaicoch, N., Thongza-ard, W., Limsuwan, S., \& Voravuthikunchai, S. P. (2012). In vitro antibacterial activity of ethanol extracts of nine herbal formulas and its plant components used for skin infections in Southern Thailand. Journal of Medicinal Plants Research, 6 (44), 56165623.

Fuchs, F. D., \& Whelton, P. K. (2020). Hypertension, reviews high blood pressure and cardiovascular disease, American heart association, 75 (2), 285-292. 
Heyne, K. (1987). Indonesian useful plants III, Jakarta; Indonesia: Sarana Wana Jaya Foundation.

Imbs, T. I., Ermakova, S. P., Fedoreyev, S. A, Anastyuk, S. D., \& Zvyagintseva, T. N. (2013). Isolation of fucoxanthin and highly unsaturated monogalactosyldiacylglycerol from brown alga Fucus evanescens C Agardh and in vitro investigation of their antitumor activity. Mar. Biotechnology, 15 (5), 606-612.

Liu, B., Yang, J., Ma, Y., Yuan, E., \& Chen, C. (2010). Antioxidant and angiotensin converting enzyme (ACE) inhibitory activities of ethanol extract and pure flavonoids from Adinandra nitida leaves, Pharmaceutical Biology, 48 (12), 1432-1438.

Muharni, M., Fitrya, F., \& Nurmaliana, R. (2016). Phytochemical screening antioxidant and antibacterial activity of traditional medicine ethnic Musi Palembang. Ministry of the Health Republic of Indonesia.

Muharni, M., Elfita, E., Yohandini, H., Yasrina Y., \& Miranti, M. (2019). Chemical constituents from stem bark of $F$. rukam Zool \& Mor. and their antioxidant activities. Sains Malaysiana, 48 (9), 1899-1906.

Muharni, Elfita, Fitrya, Anggara, K. S Yohandini, H., \& Julinar. (2019). Friedelin-triterpene from the root bark of Flacourtia rukam. Research Journal of Chemistry and Environment, 23 (12), 33-37.

Metasari, S., Elfita, E., Muharni, M., \& Yohandini, H. (2020). Antioxidant compounds from the stem bark of Syzygium samarangense L, Molekul, 15 (3), 175- 183.

Nayaka, H. B., Londonkar, R. L., Umesh, K. K., \&Tukappa, A. (2014). Antibacterial attributes of apigenin, isolated from Portulaca oleracea L. International Journal of Bacteriology, 2014: 1-8

Nguyen, A., Malonne, T., Duez, P., Vanhaelen, F. R., Vanhaelen, M., \& Fontaine, J. (2004). Cytotoxic constituents from Plumbago zeylanica. Fitoterapia, 75 (5): 500-504.

Oparil, S., Acelajado, M. C., Bakris, G. L., Berlowitz, R., Cífková, R., Dominiczak, A. F., Grassi, G., Jordan, J., Poulte, N. R., Rodgers, A., \& Whelton , P. K. (2019). Hypertension, Nature Reviews Disease Primers, 22 (4), 18014.

Ozarowski, M., Kujauski, R., Micolacjzak P. L., Wielgus, K., Klejewski, A., Wolski, H., \& Mrozikiewicz A. S. (2019). In vitro and in vivo activities of flavonoids apigenin, baicalin, chrysin, scutellarin in regulation of hypertension, a review for their possible effects in pregnancy-induced hypertension. Herba pelonica, 65 (1), 55-70.

Ragasa, C. Y., Jo, M. A. Y., Theresa, J. T., Maria, C. S., Irving, D., Robert, B., \& Sylvia, U. (2016). Chemical constituents of Flacourtia rukam Zoli. \& Moritzi fruit. International Journal of Pharmaceutical and Clinical Research, 8 (12), 1625-1628.

Shwe, H. H., Win, K. K., Moe, T. T., Myint, A. A., \& Win, T. (2019), Isolation and structural characterization of lupeol from the stem bark of Diospyros ehretioides Wall. International European Extended Enablement in Science, Engineering \& Management, 7, 140-144.

Sashidhara, K. V., Singh, S. P., Singh, S. V., Srivastava, R. K., Srivastava, K., \& Saxena, J. K. (2013). Isolation and identification of $\beta$-hematin inhibitors from Flacourtia indica as promising antiplasmodial agents. European journal of medicinal chemistry, 60, 497-502.

Thai, C. H., Duong, T. H., Trung, N. T., Phan, C. D., Nguyen, Q. V., Nguyen, T.L., Watanabe, K., Do, T.T., Huynh, T. N., \& Tran H. (2020). Rukamtenol, a new spiro compound isolated from Flacourtia rukam Zoll. \& Moritzi growing in Vietnam, Natural Product Research. 2020, 1-7.

Tsai, P. W., de Castro-Cruz, K., Shen, C. C., \& Ragasa, C. Y. (2012). Chemical constituents of Ficus odorata. Pharmaceutical Chemistry Journal, 46 (4), 225-227.

Talukder, C., Saha, S., Adhikari, S., Mondal, H. K., Islam, M. K., \& Anisuzzman, M. (2012). Evaluation of antioxidant, analgesic and antidiarrhoeal activity of Flacourtia Jangomas (Lour) rausch leaves. Pharmacology Online, 3, 20-28.

Yustian, I., Muharni, M., Sukarmi, S., Arbi, A., \& Zulaika, Z. (2012). Exploration of ethnomedicine and local community medicinal plants in Indonesia (ethnic Musi II). Palembang; Indonesia.

Zhang, S., Xin, L., Zi-Long, Z., Lu, H., Zhe, W., \& Guang-Shu, W. (2012). Isolation and identification of the phenolic compounds from the roots of Sanguisorba officinalis L. and their antioxidant activities. Molecules, 17, 1391713922. 